\title{
Performance Characteristics of Starter Broiler Chicks Fed Dietary Sun-Dried Sweet Orange Peel Meal (SOPM) with and Without Polyzyme ${ }^{\circledR}$
}

\author{
*Sunmola, T .A., Tuleun, C. D. and Oluremi, O.I.A. \\ Department of Animal Nutrition, College of Animal Science, University of Agriculture, P.M.B. 2373, Makurdi, Benue State, Nigeria \\ *Corresponding author: ta.sunmola@gmail.com \\ DOI: 10.31364/SCIRJ/v6.i8.2018.P0818555 \\ http://dx.doi.org/10.31364/SCIRJ/v6.i8.2018.P0818555
}

\begin{abstract}
The study was carried out to evaluate the performance characteristics of starter broiler chicks fed diet containing sun-dried sweet orange peel meal with and without polyzyme ${ }^{\circledR}$. Fresh sweet orange peel was collected from sweet orange fruits retail sellers and was immediately sun-dried on concrete platforms to attain less than $12 \%$ moisture. It was ground and mixed with other feed ingredients to produce six (6) experimental diets $\mathrm{T}_{1}, \mathrm{~T}_{2}, \mathrm{~T}_{3}, \mathrm{~T}_{4}, \mathrm{~T}_{5}$ and $\mathrm{T}_{6}$. Two hundred and sixteen (216) unsexed day-old Abor acer plus broiler chicks were randomly assigned to the six dietary treatments of 36 chicks each and 12 chicks per replicate. The experimental diets had 2 levels of Polyzyme ${ }^{\circledR}(0 \%$ and $0.04 \%)$ and 3 levels of sun-dried sweet orange peel meal $(15 \%, 20 \%$ and $25 \%)$ and the experimental was fitted into the completely randomized design. Chicks were fed these diets $\mathrm{T}_{1}-15 \%$ sun-dried sweet orange peel meal $+0 \%$ polyzyme $^{\circledR}, \mathrm{T}_{2} .20 \%$ sun-dried sweet orange peel meal $+0 \%$ polyzyme $^{\circledR}, \mathrm{T}_{3}-25 \%$ sun-dried sweet orange peel meal +0 $\%$ polyzyme $^{\circledR}, \mathrm{T}_{4} .15 \%$ sun-dried sweet orange peel meal $+0.04 \%$ polyzyme ${ }^{\circledR}, \mathrm{T}_{5} .20 \%$ sun-dried sweet orange peel meal $+0.04 \%$ polyzyme $^{\circledR}$ and $\mathrm{T}_{6} .25 \%$ sun-dried sweet orange peel meal $+0.04 \%$ polyzyme $^{\circledR}$. Broiler chicks fed $15 \%$ dietary SOPM with and without polyzyme ${ }^{\circledR}$ had significantly $(\mathrm{P}<0.05)$ highest final weight, weight gain and feed intake. Experimental diets did not show significant effect $(\mathrm{P}>0.05)$ on dry matter, crude protein, crude fibre and nitrogen free extract digestibility. There was interaction between polyzyme ${ }^{\circledR}$ and sweet orange peel meal on nitrogen free extract at $15 \%$ and $25 \%$ which was influenced by polyzyme ${ }^{\circledR}$. There was no detrimental effect of SOPM and polyzyme ${ }^{\circledR}$ production cost. It is therefore concluded from this trial that sun-dried sweet orange peel meal has some nutritional benefits in the diet of broiler chicks and that inclusion level of sun-dried sweet orange peel meal up to $25 \%$ without and with polyzyme ${ }^{\circledR}$ level of $0 \%$ and $0.04 \%$ did not have deleterious effect on broiler chicks growth performance and production cost.
\end{abstract}

Keywords: Orange, polyzyme ${ }^{\circledR}$, broiler, chicks, performance.

\section{Introduction}

The soaring demand for global corn, for human consumption and industries has led to increase in price of corn and corresponding increase in livestock feed cost and animal products (meat and eggs). This is one of the major limiting factors in poultry production as the cost of feed alone accounts for about $70-75 \%$ of the total cost of broiler production (Jurgens et al., 2009). In addition to price, world grain production has also been declined in the past years due to the crops compete for land (Attamangkune, 2007). The use of cereal by-products that are cheap, locally available and have no direct nutritional value to mankind therefore appears to be one of the approaches for solving the feed crises that is having negative effect on livestock industry most especially non ruminant animal production. One of such alternatives is the sweet orange (Citrus sinensis) peel. According to Chapman et al. (2000), a number of residue materials like peels, rag, seed, etc. are produced when fresh citrus fruits are processed into juice, concentrates and canned fruits in developed countries. In Nigeria, sweet orange is consumed on a wide scale, and the peels are usually considered as wastes which at times are seen littered on the streets and along the road due to the fact that the Nigerian Government and orange retailers have not developed strategic disposal programme. As such, orange peels have become an environmental problem (Oluremi et al., 2007).

Sweet orange fruit peel has been observed to be a source of calorie and protein comparable with maize grain (Oluremi, 2008). Besides Neal et al. (1999) reported that dried grape fruit waste materials are good for growing animals based on the nutritive and digestible nutrients contained therein. Thus far, nutritional trials with monogastric animals have shown that the meal of sun-dried sweet orange peels of Citrus sinensis can replace up to $20 \%$ of dietary maize in broiler diet (Agu et al., 2010) and $40 \%$ in rabbit (Oluremi et al., 2005), without any adverse effect on their performance. The use of exogenous microbial enzymes to improve the nutritional value of high fiber diets have been well documented (Angelovicova et al., 2005; Raza et al., 2009). The utilization of exogenous enzymes has been shown to improve nutrient digestibility, destroy anti-nutritional factors and manipulate gut flora population as well as 
supplementing endogenous enzymes (Bedford, 1996). Classen and Bedford (1999) reported improved nutrient utilization when poultry birds were fed wheat-based diets supplemented with crude enzyme preparation having high xylanase activity. The Polyzyme ${ }^{\circledR}$ contains xylanase, phytase, cellulase, $\beta$ - glucanase, pectinases, $\alpha$ - amylase, protease, $\alpha$ - galactosidase, $\beta$ - galactosidase, lipase and mannanase all of which are able to digest complex carbohydrates at the company recommendation dose of $400 \mathrm{gm}$ per ton of mash feed. Therefore, this experiment was conducted to determine the effect of partial replacement of maize with dietary sun-dried sweet orange peel with and without enzyme treatment on growth performance, nutrient digestibility and economic of production of starter broiler chicks.

\section{Materials and Methods}

\section{Experimental Site}

The study was conducted at the Poultry House of the Livestock unit, Teaching and Research Farm, Federal University of Agriculture, Makurdi, Benue State. Makurdi is located between latitude $7^{0} 44^{\prime} \mathrm{N}$ and longitude $8^{0} 21^{\prime} \mathrm{E}$ in the Guinea Savanna Zone of West Africa. The area has an annual rainfall between 6 - 8 months (March - October) and ranging from 508 to $1016 \mathrm{~mm}$ with a minimum temperature range of $24.20 \pm 1.4^{\circ} \mathrm{C}$ and maximum temperature range of $36.33 \pm 3.70^{\circ} \mathrm{C}$. The relative humidity ranges between 39.50 $\pm 2.20 \%$ and $64.00 \pm 4.80 \%($ TAC, 2011).

\section{Collection and Preparation of Test Ingredients}

The test ingredient, sweet orange (Citrus sinensis) fruit peel was collected fresh from orange retail sellers on the university campus and clean of dirt. To prevent fermentation and other forms of deterioration, the peel was immediately sun-dried on concrete platforms to attain less than $12 \%$ moisture. It was milled to obtain the sweet orange peel meal and stored for use in feed formulation for the broiler chicks

\section{Experimental Birds and management}

Before the feeding trial, the deep litter poultry house was thoroughly cleaned, washed and disinfected with $1 \%$ formalin solution. Heat and light were provided 24 hours daily throughout the brooding period of 14 days. Adequate cross ventilation for more conducive environment was ensured throughout the experimental period and standard hygienic practices were also maintained throughout the 42 days experimental period. Feed and water were provided ad-libitum

\section{Experimental Diets and Design}

Two hundred and fifty two (216) unsexed day old Abor acre plus broiler chicks were obtained from Vertex Farms in Ibadan and used for this experiment. The birds were randomly distributed in $2 \times 3$ factorial designs with two levels of polyzyme ${ }^{\circledR}(0 \%$ and $0.04 \%)$ and three levels of sun-dried sweet orange peel meal $(15 \%, 20 \%$ and $25 \%)$ making six treatments, each having three replicates with twelve (12) chicks per replicate, housed in a deep litter compartments. All the diets were iso-nitrogenous and iso-caloric as shown in Table 1.

\section{Data collection:}

Feed intake was calculated as difference in the quantity of feed given and left over after 24 hour. Weight gain was determined as the difference in the weight of the birds after 7 days period. Feed: grain ratio was calculated from feed intake and weight gain. Protein conversion ratio was calculated by multiply feed intake by dietary protein intake divided by body weight gain. Cost of feed was calculated from the cost of ingredients used in feed preparation. Feed cost per kilogram live weight gain was calculated from feed cost and feed: gain ratio. Feed cost per weight gain was calculated by multiply the feed cost per kg with total feed intake and divided by total weight gain. Feed cost/chick was calculated by multiply feed intake per day by the number of days then multiplies by feed cost per kilogram. Operational cost per bird was calculated by adding all other expenses except expenses on feed and day old broiler chick. Cost savings due to SOPM was calculated by subtracting total cost of production of each treatment from total cost of production of the broiler chickens fed control diet. Total cost of production was calculated by adding cost of day old chick, feed cost per chick and operational cost. Feed cost as a percentage of total production cost was calculated by dividing cost of feed per $\mathrm{kg}$ with total cost of production and multiply by hundred.

\section{Nutrient Digestibility}

Determination of nutrient digestibility was done at the end of the starter phase of the experimental period. Two birds per replicate were selected and transferred into metabolic cages. The first 3 days was allowed for adaptation of birds and the respective diets were offered liberally. Daily feed intake and daily faecal output was recorded for 4 days. The droppings were collected per replicate once 
daily at 8:00 am, weighed and dried in an oven at $70^{\circ} \mathrm{C}$ to constant weight. Dried excreta were bulked, milled and the representative samples taken for proximate analysis.

\section{Chemical analysis:}

Proximate composition of Sweet orange peel meal, feeds and excreta were determined using AOAC (2006) methods of analysis, while the metabolizable energy was calculated using the equation; $\mathrm{ME}(\mathrm{kcal} / \mathrm{kg})=37 \times \% \mathrm{CP}+81.1 \times \% \mathrm{EE}+35.5 \times \% \mathrm{NFE}$ (Pauzenga, 1985).

\section{Statistical Analysis}

All generated data were subjected to two-way analysis of Variance (ANOVA) using SAS (2008) software package and the means were separated using Duncan's Multiple Range Test (DMRT). All statements of significance are based on the 0.05 level of probability.

Table 1. Gross Composition of the Experimental Broiler Starter Diets

\begin{tabular}{|c|c|c|c|c|c|c|}
\hline \multirow{3}{*}{$\begin{array}{l}\text { Enzyme Levels } \\
\text { SOPM levels }\end{array}$} & \multicolumn{6}{|c|}{ Experimental diets } \\
\hline & \multicolumn{3}{|c|}{$0 \%$} & \multicolumn{3}{|c|}{$0.04 \%$} \\
\hline & $15 \%$ & $20 \%$ & $25 \%$ & $15 \%$ & $20 \%$ & $25 \%$ \\
\hline Treatments & $\mathrm{T}_{1}$ & $\mathrm{~T}_{2}$ & $\mathrm{~T}_{3}$ & $\mathrm{~T}_{4}$ & $\mathrm{~T}_{5}$ & $\mathrm{~T}_{6}$ \\
\hline \multicolumn{7}{|l|}{ Ingredients } \\
\hline White maize & 44.71 & 42.08 & 38.45 & 44.67 & 42.04 & 39.41 \\
\hline SOPM & 7.89 & 10.52 & 13.15 & 7.89 & 10.52 & 13.15 \\
\hline Soya bean meal & 37.35 & 37.35 & 37.35 & 37.35 & 37.35 & 37.35 \\
\hline Rice bran & 3.25 & 3.25 & 3.25 & 3.25 & 3.25 & 3.25 \\
\hline Blood meal & 2.00 & 2.00 & 2.00 & 2.00 & 2.00 & 2.00 \\
\hline Bone meal & 3.00 & 3.00 & 3.00 & 3.00 & 3.00 & 3.00 \\
\hline Palm oil & 1.00 & 1.00 & 1.00 & 1.00 & 1.00 & 1.00 \\
\hline Herbo-Methionine & 0.15 & 0.15 & 0.15 & 0.15 & 0.15 & 0.15 \\
\hline Premix* & 0.25 & 0.25 & 0.25 & 0.25 & 0.25 & 0.25 \\
\hline L-Lysine & 0.20 & 0.20 & 0.20 & 0.20 & 0.20 & 0.20 \\
\hline Common salt & 0.20 & 0.20 & 0.20 & 0.20 & 0.20 & 0.20 \\
\hline Enzyme & - & - & - & + & + & + \\
\hline Total & 100 & 100 & 100 & 100 & 100 & 100 \\
\hline \multicolumn{7}{|l|}{ Calculated analysis } \\
\hline **ME (Kcal/kg) & 2888 & 2876 & 2864 & 2888 & 2876 & 2864 \\
\hline Crude protein (\%) & 23.82 & 22.98 & 22.93 & 23.82 & 22.98 & 22.93 \\
\hline Crude fibre (\%) & 5.19 & 5.46 & 5.77 & 5.19 & 5.46 & 5.77 \\
\hline Ether extract (\%) & 3.94 & 4.04 & 4.14 & 3.94 & 4.04 & 4.14 \\
\hline Lysine (\%) & 1.46 & 1.45 & 1.45 & 1.46 & 1.45 & 1.45 \\
\hline Methionine (\%) & 0.62 & 0.61 & 0.61 & 0.62 & 0.61 & 0.61 \\
\hline Calcium (\%) & 1.04 & 1.04 & 1.04 & 1.04 & 1.04 & 1.04 \\
\hline Available P (\%) & 0.87 & 0.86 & 0.84 & 0.87 & 0.86 & 0.84 \\
\hline
\end{tabular}

*To provide the following per $\mathrm{kg}$ of diet vitamin A - 15,000.00IU, Vitamin D3 - 3, 000,000IU, Vitamin E- 30,000IU,Vitamin K3,000mgVitamin B1 3000,mg Vitamin B2-6000mg, Vitamin B- 5,000mg, Vitamin B12-40mg, Biotin 200mg, Niacin-40,000mg, Pantothenic acid 15,000mg,Folic acid 2,000mg, choline 300,000mg,Iron 60,000mg, manganese 80,000mg, copper 25,000mg,Zinc 80,000mg cobalt 150mg, iodine 500mg, selenium 310mg, Antioxidant 20,000mg. 
**ME kcal $/ \mathrm{kg}$ calculated using $37 \mathrm{X} \% \mathrm{CP}+81.1 \mathrm{X} \% \mathrm{EE}+35.5 \mathrm{X} \% \mathrm{NFE}($ Pauzenga, 1985) SOP $=$ Sweet orange peel meal; $(-)=$ No enzyme; $(+)=0.04 \%$ with enzyme; $\mathrm{P}=$ Phosphorus; $\mathrm{ME}=$ Metabolizable energy; $\mathrm{T}_{1}$ Maize: replaced at $15 \%$ sun-dried sweet orange peel meal without polyzyme ${ }^{\circledR}, \mathrm{T}_{2}$ Maize: replaced at $20 \%$ sun-dried sweet orange peel meal without polyzyme ${ }^{\circledR}, \mathrm{T}_{3}$ : Maize replaced at $25 \%$ sun-dried sweet orange peel meal without polyzyme ${ }^{\circledR}, \mathrm{T}_{4}$ : Maize replaced at $15 \%$ sun-dried sweet orange peel meal plus $0.04 \%$ polyzyme ${ }^{\circledR}, \mathrm{T}_{5}$ : Maize replaced at $20 \%$ sun-dried sweet orange peel meal plus $0.04 \%$ polyzyme ${ }^{\circledR}, \mathrm{T}_{6:}$ Maize replaced at $25 \%$ sun-dried sweet orange peel meal plus $0.04 \%$ polyzyme $^{\circledR}$

\section{Results and Discussion}

The proximate composition and energy content of sweet orange peel meal and maize used in this study is presented in Table 2 . The proximate composition of sweet orange peel meal (Citrus sinensis) had crude protein (CP) and metabolizable energy (ME) contents of $8.20 \%$ and $3079.61 \mathrm{kcal} / \mathrm{kg}$ ME respectively. The CP $8.20 \%$ in the peels were lower than CP in maize, a

Table 2. Proximate Composition and Energy Content of Sweet Orange (Citrus sinensis) Peel meal and Maize (\% DM)

\begin{tabular}{llc}
\hline Nutrients (\%) & \multicolumn{2}{c}{ Feedstuff } \\
\cline { 2 - 3 } Dry matter & ${ }^{1}$ SOPM & ${ }^{2}$ Maize \\
Crude protein & 89.20 & 86.50 \\
Crude fibre & 8.20 & 9.10 \\
Ether extract & 13.30 & 1.30 \\
Ash & 4.51 & 4.00 \\
Nitrogen free extract & 6.09 & 2.70 \\
${ }^{3} \mathrm{ME} \mathrm{kcal} / \mathrm{kg}$ & 67.90 & 83.00 \\
\hline
\end{tabular}

${ }^{1}$ Laboratory Analysis; ${ }^{2}$ Aduku (2005); ${ }^{3}$ Metabolizable energy as determined using Pauzenga (1985) SOPM = Sweet orange peel meal

conventional energy feedstuff with CP content of $9.25 \%$ (Tuleun et al., 2005), while crude fibre (CF) of $13.30 \%$ in the peel was higher than $2.20 \% \mathrm{CF}$ reported for maize. The high $\mathrm{CF}$ in the peel may reduce its feeding value compared to conventional dietary maize in poultry nutrition; however the energy contents of both SOPM used in this study (3079.61 kcal $/ \mathrm{kg})$ and maize $(3432 \mathrm{kcal} / \mathrm{kg}$ ) were comparable. Ojabo et al. (2014) reported $86.20 \% \mathrm{DM}, 7.40 \% \mathrm{CP}, 8.19 \%$ ash, $7.19 \% \mathrm{EE}, 13.50 \% \mathrm{CF}, 62.65 \% \mathrm{NFE}$ and $3674.44 \mathrm{kcal} / \mathrm{kg}$ ME for sun-dried sweet orange peel meal while Agu et al. (2010) reported $89.65 \% \mathrm{DM}, 10.74 \% \mathrm{CP}, 7.86 \%$ ash, $12.00 \% \mathrm{EE}, 11.90 \% \mathrm{CF}, 56.91 \% \mathrm{NFE}$ and $3988.70 \mathrm{kcal} / \mathrm{kgME}$. Also, $7.0 \% \mathrm{CP}, 12.50 \% \mathrm{CF}$ and ME of $3420 \mathrm{kcal} / \mathrm{kg}$ reported by Ashbell and Weinbegger (1999) in Israel for sweet orange peel. Therefore, the results of proximate composition of SOP showed that it some nutritional benefits that can make it to be used in broiler chickens diets with proper handling.

The performance of starter broiler chicks fed diets containing dietary SOPM with and without polyzyme treatment is shown in Table 3. All groups of starter broiler chicks had initial weight of between $33.54-33.64 \mathrm{~g}$. The final body weight ranged from $688.64-$ 843.69 (g/bird). Dietary SOPM significantly $(\mathrm{P}<0.05)$ influenced average final weight, average weight gain, average feed intake and feed conversion ratio. This may be attributed to high fibre in sweet orange peel. Similar observation was also reported by Abbas $e t$ al. (2013) on broiler chicks fed sweet orange peel based diet. Significantly $(\mathrm{P}<0.05)$ highest value of average final weight and average weight gain was recorded on broiler chicks fed $15 \%$ dietary the performance. The least value was recorded on broiler chicks fed $20 \%$ dietary SOPM, though, not significantly ( $>>0.05)$ differed from the broiler chicks fed $25 \%$ dietary SOPM. The values of daily weight gain and daily feed intake obtained for starter broiler chicks were above the expected minimum value of $19 \mathrm{~g}$ and $37 \mathrm{~g}$ respectively, reported by Aduku (2005). The broiler chicks fed $15 \%$ dietary SOPM had significantly $(\mathrm{P}<0.05)$ best value of average feed intake and feed conversion ratio compared with the broiler chicks fed $20 \%$ dietary SOPM but not significantly $(\mathrm{P}>0.05)$ differed from the broiler chicks fed $25 \%$ dietary SOPM. This may be attributed to low fibre content of the diet compared to those fed $20 \%$ and $25 \%$ dietary SOPM. Significant interactions were observed between dietary level of sweet orange peel and addition of polyzyme on protein conversion ratio (Table 4). Sweet orange peel meal and polyzyme had no significant $(\mathrm{p}<0.05)$ interaction effect

Table 3. Effect of Experimental Diets on Growth Performance of Broiler Starter Chicks 


\begin{tabular}{lllllll}
\hline Dietary treatments & AIW $($ g) & AFW $($ g) & AWG $(g)$ & AFI $(g)$ & FCR & PCR \\
\hline
\end{tabular}

\section{SOPM levels}

$\begin{array}{lllllll}15 \% & 33.54 & 843.69^{\mathrm{a}} & 28.93^{\mathrm{a}} & 44.64^{\mathrm{a}} & 1.54^{\mathrm{b}} & 0.34^{\mathrm{b}} \\ 20 \% & 33.64 & 688.64^{\mathrm{b}} & 23.39^{\mathrm{b}} & 37.28^{\mathrm{b}} & 1.59^{\mathrm{ab}} & 0.35^{\mathrm{ab}} \\ 25 \% & 33.59 & 706.31^{\mathrm{b}} & 24.03^{\mathrm{b}} & 40.72^{\mathrm{ab}} & 1.70^{\mathrm{a}} & 0.38^{\mathrm{a}}\end{array}$

Polyzyme levels

\begin{tabular}{lllllll}
$0 \%$ & 33.57 & 752.02 & 25.66 & 40.67 & 1.59 & 0.37 \\
$0.04 \%$ & 33.60 & 740.40 & 25.24 & 41.09 & 1.63 & 0.38 \\
SEM & 0.03 & 34.63 & 1.24 & 1.98 & 0.02 & 0.03 \\
\hline
\end{tabular}

${ }_{\mathrm{a}, \mathrm{b}}$ Means within each column with different superscripts are significantly different $(\mathrm{P}<0.05)$. ns - not significantly different $(\mathrm{P}>0.05)$; * significantly different $(\mathrm{P}<0.05)$ Note: AIW = average initial weight; AFW = average final weight; AWG = average weight gain; $\mathrm{AFI}=$ average feed intake; FCR $=$ feed conversion ratio; $\mathrm{PCR}=$ Protein conversion ratio; $\mathrm{SEM}=$ standard error of mean; $\mathrm{SOPM}-$ Sweet orange peel meal

Table 4. Interaction Effect of Dietary Sweet Orange Peel meal and Enzyme Treatment on Starter Broiler Chicks Growth Performance

\begin{tabular}{lcclllll}
\hline $\begin{array}{l}\text { Enzyme } \\
\text { Levels }\end{array}$ & $\begin{array}{c}\text { SOPM } \\
\text { Levels }\end{array}$ & AIW $(\mathbf{g})$ & AFW $(\mathbf{g})$ & AWG (g/d) & AFI (g/d) & FCR & PCR \\
& $15 \%$ & 33.53 & $823.74^{\mathrm{a}}$ & $28.22^{\mathrm{a}}$ & $42.05^{\mathrm{ab}}$ & $1.49^{\mathrm{b}}$ & 0.34 \\
$\mathbf{0 \%}$ & $20 \%$ & 33.63 & $704.55^{\mathrm{b}}$ & $23.96^{\mathrm{b}}$ & $37.50^{\mathrm{b}}$ & $1.57^{\mathrm{b}}$ & 0.35 \\
& $25 \%$ & 33.53 & $727.78^{\mathrm{b}}$ & $24.79^{\mathrm{b}}$ & $42.47^{\mathrm{ab}}$ & $1.72^{\mathrm{a}}$ & 0.38 \\
& $15 \%$ & 33.53 & $863.64^{\mathrm{a}}$ & $29.64^{\mathrm{a}}$ & $47.24^{\mathrm{ab}}$ & $1.59^{\mathrm{a}}$ & 0.37 \\
$\mathbf{0 . 0 4 \%}$ & $20 \%$ & 33.63 & $672.73^{\mathrm{b}}$ & $22.82^{\mathrm{b}}$ & $37.07^{\mathrm{b}}$ & $1.61^{\mathrm{ab}}$ & 0.37 \\
& $25 \%$ & 33.63 & $684.55^{\mathrm{b}}$ & $23.25^{\mathrm{b}}$ & $38.96^{\mathrm{b}}$ & $1.67^{\mathrm{a}}$ & 0.38 \\
$\mathbf{S E M}$ & & $0.00^{\mathrm{ns}}$ & $0.03^{*}$ & $1.08^{*}$ & $1.25^{*}$ & $0.02^{*}$ & $0.03^{\mathrm{ns}}$ \\
\hline
\end{tabular}

a,b Means within each column with different superscripts are significantly different $(\mathrm{P}<0.05)$. ns -not significantly different $(\mathrm{P}>0.05)$; * significantly different $(\mathrm{P}<0.05)$. Note: AIW = average initial weight; $\mathrm{AFW}=$ average final weight; $\mathrm{AWG}=$ average weight gain; AFI $=$ average feed intake; FCR $=$ feed conversion ratio; $\mathrm{PCR}=$ Protein conversion ratio; $\mathrm{SEM}=$ standard error of mean; SOPM $-\mathrm{Sweet}$ orange peel meal

on average final weight, average daily weight, average feed intake and feed conversion ratio of the birds at $15 \%, 20 \%$ and $25 \%$. At $15 \%$ sweet orange peel inclusion however, addition of polyzyme significantly $(\mathrm{P}<0.05)$ influenced the interaction effect on protein conversion ratio. Brenes et al. (1993) also reported improvement in protein utilization of chicks fed barley containing diets as a result of enzyme addition. The nutrient digestibility of starter broiler chicks fed dietary SOPM is shown in Table 5.Nutrient digestibility values showed that birds in all dietary groups were not significantly $(\mathrm{P}>0.05)$ affected by the diets, except for ether extract where the value obtained on broiler chicks fed $15 \%$ dietary SOPM was significantly $(\mathrm{P}<0.05)$ highest than that obtained for the broiler chicks fed $20 \%$ and $25 \%$ dietary SOPM. This was not in line with the findings of Ojabo et al. (2014) who reported significantly $(\mathrm{P}<0.05)$ differences of all nutrient digestibility on pullet chicks fed dietary SOP between $20-40 \%$, this may be attributed to the different types of the birds used for the study. The similarity in the nutrient digestibility values for all nutrients across the dietary treatments showed that the birds were able to digest the nutrients optimally. Diets containing dietary SOPM at substitution levels of $25 \%$ proved to be less digested as the ether extract digestibility progressively decrease significantly $(\mathrm{P}<0.05)$ as the level of dietary SOPM in the 
diets increased from $15 \%$ to $25 \%$. There was no interaction effect between dietary SOPM and polyzyme across the dietary treatment except for nitrogen free extract at $15 \%$ and $25 \%$ inclusion level of dietary SOPM which was improved by addition of polyzyme (Table 6). The nitrogen free extract improvement may indicate that the level of dietary SOP of $15 \%-25 \%$ and polyzyme $0 \%-0.04$ $\%$ used are not detrimental to the starter broiler chicks nutrients digestibility. Significant improved nitrogen free extract observed on broiler chicks fed $15 \%$ and $25 \%$ dietary SOPM may imply that polyzyme enhanced the readily available carbohydrate of the diet. The cost implication of feeding graded levels of processed sweet orange peel to starter broiler chicks is shown in Table 7 . As the SOPM/maize replacement levels increased, the feed cost progressively decreased in both groups fed dietary SOPM with and without polyzyme. The progressive decreased is in line with the report of Ani et al. (2012); Ojabo et al. (2014); Ngiki et al. (2014) and Olaifa et al. (2015) who reported that the feed cost per weight gain decreased with increased dietary levels of bambara nut, sweet orange peel, cassava root-leaf meal mixture and cassava peel meal based diet respectively on broiler chickens. The broiler chicks fed dietary SOPM with polyzyme attracted relatively higher cost of feed compared to those fed dietary SOPM without polyzyme. This was as a result of the additional cost of polyzyme. The cost per day old broiler chick amounted to $\$ 0.305$ across the dietary treatments. Broiler chicks fed $25 \%$ dietary SOPM with polyzyme had better feed cost per weight gain compared to the broiler chicks fed $25 \%$ dietary SOPM without polyzyme. Highest feed cost per weight gain recorded on broiler chicks fed $15 \%$ and $20 \%$ with polyzyme compared with $15 \%$ and $20 \%$ without polyzyme was the function of highest feed consumed that was inefficiently converted and utilised. Cost savings due to sweet orange peel increased with increased levels of sweet orange peel as a replacement for maize (conventional feed). Broiler chicks fed $15 \%$ dietary SOPM in both groups recorded the highest amount of feed cost per kg which was associated with the highest feed intake.

Table 5. Effect of Experimental Diets on Nutrients Digestibility of Broiler Starter Chicks

\begin{tabular}{lllllll}
\hline Dietary treatments & & DM & CP & CF & EE & NFE \\
\hline SOPM level & $15 \%$ & 90.33 & 88.78 & 87.44 & $89.23^{\mathrm{a}}$ & 93.15 \\
& $20 \%$ & 89.92 & 88.78 & 80.50 & $87.81^{\mathrm{ab}}$ & 92.42 \\
& $25 \%$ & 90.17 & 87.75 & 85.62 & $86.81^{\mathrm{b}}$ & 92.70
\end{tabular}

Polyzyme level

$\begin{array}{llllll}0 \% & 90.09 & 88.27 & 83.40 & 87.74 & 92.29 \\ 0.04 \% & 90.19 & 88.08 & 85.64 & 88.16 & 93.22\end{array}$

SEM

0.52

0.72

$1.13 \quad 0.85$

0.68

${ }^{\mathrm{a}, \mathrm{b}}$ Means within each column with different superscripts are significantly different $(\mathrm{P}<0.05)$. ns - not Significantly different $(\mathrm{P}>0.05)$;

* Significantly different $(\mathrm{P}<0.05) . \mathrm{DM}=$ Dry Matter; $\mathrm{CP}=$ Crude protein; $\mathrm{CF}=$ Crude Fibre; EE $=$ Ether Extract; NFE = Nitrogen Free Extract; SEM = standard error of mean; SOPM = Sweet orange peel meal; NS = No significant

Table 6. Interaction Effect of Enzyme and Sweet Orange Peel Meal on the Dry Matter and Nutrient Starter Broiler chicks

Digestibility of the

\begin{tabular}{lllllll}
\hline Enzyme level & SOPM level & DM & CP & CF & EE & NFE \\
\hline & $15 \%$ & 90.27 & 88.69 & 87.42 & $88.68^{\mathrm{ab}}$ & $92.73^{\mathrm{b}}$ \\
$0 \%$ & $20 \%$ & 89.91 & 87.24 & 77.28 & $87.07^{\mathrm{ab}}$ & $92.04^{\mathrm{b}}$ \\
& $25 \%$ & 90.09 & 88.03 & 85.50 & $87.46^{\mathrm{ab}}$ & $92.11^{\mathrm{b}}$ \\
& $15 \%$ & 90.39 & 88.87 & 87.45 & $89.78^{\mathrm{a}}$ & $93.56^{\mathrm{a}}$ \\
& $20 \%$ & 89.93 & 87.92 & 83.72 & $88.54^{\mathrm{ab}}$ & $92.80^{\mathrm{b}}$ \\
& $25 \%$ & 90.24 & 87.46 & 85.74 & $86.16^{\mathrm{a}}$ & $93.29^{\mathrm{a}}$ \\
& & $0.34^{\mathrm{ns}}$ & $0.63^{\mathrm{ns}}$ & $1.01^{\mathrm{ns}}$ & $0.53^{*}$ & $0.42^{*}$ \\
\hline
\end{tabular}


${ }^{a, b}$ Means within each column with different superscripts are significantly different $(\mathrm{P}<0.05)$. ns - not significantly different $(\mathrm{P}>0.05)$; * significantly different $(\mathrm{P}<0.05)$. E - Enzyme; SOPM - Sweet orange peel meal; DM = Dry Matter; CP = Crude Protein; CF = Crude Fibre; EE = Ether Extract; NFE = Nitrogen free extract SEM = standard error of mean; SOPM - sweet orange peel meal

Table 7. Economics of Production of Starter Broiler Chicks Fed Diets Containing Sweet Orange Peel Meal with and without Enzyme

\begin{tabular}{|c|c|c|c|c|c|c|}
\hline \multirow[t]{2}{*}{ Economic Indices } & \multicolumn{4}{|c|}{ Experimental diets } & \multirow[b]{2}{*}{$\mathrm{T}_{5}$} & \multirow[b]{2}{*}{$\mathrm{T}_{6}$} \\
\hline & $\mathrm{T}_{1}$ & $\mathrm{~T}_{2}$ & $\mathrm{~T}_{3}$ & $\mathrm{~T}_{4}$ & & \\
\hline C of DOC $(\$)$ & 0.305 & 0.305 & 0.305 & 0.305 & 0.305 & 0.305 \\
\hline $\mathrm{FC} / \mathrm{kg}(\$)$ & 0.392 & 0.381 & 0.368 & 0.394 & 0.383 & 0.367 \\
\hline FC/WG $(\$ / k g)$ & 0.584 & 0.596 & 0.623 & 0.628 & 0.622 & 0.615 \\
\hline FC/chicks (\$) & 0.459 & 0.400 & 0.434 & 0.520 & 0.398 & 0.400 \\
\hline $\mathrm{OPC}(\$)$ & 0.389 & 0.389 & 0.389 & 0.389 & 0.389 & 0.389 \\
\hline TCP (\$/chick) & 1.153 & 1.094 & 1.129 & 1.152 & 1.093 & 1.095 \\
\hline CS due to SOPM (\$/chick) & 0.154 & 0.213 & 0.178 & 0.092 & 0.214 & 0.213 \\
\hline $\mathrm{FC}(\% \mathrm{TCP})$ & 0.110 & 0.101 & 0.106 & 0.119 & 0.101 & 0.101 \\
\hline $\mathrm{C}$ of DOC $(\% \mathrm{TCP})$ & 0.073 & 0.077 & 0.075 & 0.069 & 0.077 & 0.077 \\
\hline
\end{tabular}

FC = feed cost $;$ CS = Cost savings $;$ DOC = Day old chicks $; \mathrm{C}=$ Cost $; \mathrm{TCP}=$ Total cost of production; OP $=$ Operational cost; $\mathrm{T}_{1}=15$ $\%$ SOPM without enzyme; $\mathrm{T}_{2}=20 \% \mathrm{SOPM}$ without enzyme; $\mathrm{T}_{3}=25 \%$ SOPM without enzyme; $\mathrm{T}_{4}=15 \% \mathrm{SOPM}$ with enzyme; $\mathrm{T}_{5}=$ $20 \%$ SOPM with enzyme; $\mathrm{T}_{6}=25 \%$ SOPM with enzyme, $\mathrm{SOPM}=$ sweet orange peel meal

\section{Conclusion}

Sun-dried sweet orange peel meal has some comparable nutritional benefits to maize and can be used in the diet of broiler chicks. Progressive replacement of dietary maize up to $25 \%$ level with or without polyzyme in broiler starter chicks diets had no depressive effects on performance and nutrient digestibility.

\section{References}

Abbas. E., Ali, A.A.Q., Alireza, S., Vito, L. \& Vincenzo, T. (2013). Effect of different levels of dried sweet orange (Citrus sinensis) peel on broiler chickens growth performance. Italian Journal of Animal Science (2) 11-17

Aduku, A.O. (2005). Tropical Feedstuff Analysis Table. Department of Animal Science, Ahmadu Bello University, Samaru, Zaria, Nigeria. $\mathrm{Pg} 4$

Agu, P.N., Oluremi, O.I.A. \& Tuleun, C.D. (2010). Nutritional evaluation of sweet of orange (Citrus sinensis) fruit peel as feed resource in broiler production. International Journal of Poultry Science, 9: 684-688.9.

Angelovicova, M., Jan, M., Marek, A. \& Miroslava, K. (2005). Effect of enzyme addition to wheat based diets in broiler. Trakya University Journal of Science, 6(1): 29-33.

Ani, A.O., Ugwuowo, L.C. \& Omeje, O.D. (2012). Growth performance of broilers chicks fed diets containing raw bambara nut (Vigna subterranea L) waste and supplementary enzyme. African Journal of Biotechnology.11 (56):11991-11997 
AOAC. (2006). Official methods of analysis. Association of Official and Analytical Chemists. 17th Edition,Washington.

Ashbell, G \& Weinbeger Z. G. (1999). Silage production and utilization. http://www.fao.org/ag/AGP/AGPC/doc/silage/silageIsrael/silage- Israel.htm\#8

Attamangkune, S. (2007). Utilization of bulky feed ingredients in pig and poultry diets. 15th annual ASAIM Southeast Asian Feed Technology and Nutrition Workshop. May 27-30, Conrad Bali Resort.Indonesia. Bedford, M., 1996. The effect of enzyme on digestion. Journal Applied Poultry Research, 5: 370-377.

Bedford, M. (1996). The effect of enzyme on digestion. Journal of Applied Poultry Research. 5: 370-377.

Brenes, A., Smith, M., Guenter, W. \& arquardt, R.R. (1993). Effect of enzyme supplementation on the performance and digestive tract size of broiler chicken fed wheat-and barely-based diets. Poultry Science, 72(9): 1731-1739.

Chapman, H.L., Ammerman, C.B., Baler, F.S., Henteges, J.F., Hages, B.W. \& Cunha, J.J. (2000). Citrus feed for Beef Cattle. Reviewed Bulletin.751.Dept. Of Animal Science, Florida Coop. Extension Service Institute of Florida and Agric. Science, University of Florida, USA.

Classen, H.L. and Bedford, M.R. (1999). The Use of Enzymes to Improve the Nutritive Value of Poultry Feeds. Recent Advances in Animal Nutrition, Butter worth, Heinemann Ltd., Oxford.

Jurgens., M.H., Lee, I. \& Chibam, C. (2009). Poultry Nutrition and Feeding. Animal Nutrition Handbook. $2002 ; 316$. Available:http://www.ag.auburn.edu/ chiba le/an12poultryfeeding.pdf

Neal, R.W. \& Stovers, F.A. (1999). Poultry management in the tropics production, processing, utilization, marketing, economics, research and future prospects living books series, UK.; 20-24.

Ngiki, Y. U., Igwebuike, J. U. \& Moruppa, S. M. (2014). Effects of Replacing Maize with Cassava Root-Leaf Meal Mixture on the Performance of Broiler Chickens. International Journal of Science and Technology Volume 3 No. 6, June, 2014

Ojabo, L.D., Oluremi, O.I.A. \& Uza, D.V. (2014). Effect of feeding sun-dried sweet orange (Citrus sinensis) fruit peel on pullet chick performance. Research Opinion of Animal Veterinary Science, 4(9): 484-488.

Olaifa, R.O., Adeyemi,O.A., Oloyede, S.T., Sogunle, O.M., Agunbiade, J.A. \& Okubanjo, A.O. (2015). Performance and carcass characteristics of broiler chickens fed graded levels of cassava peel meal based diets. Malasia Journal of Animal Science. 18(2): $103-112$

Oluremi, O.I.A., Ngi, J. \& Andrew, I.A. (2007). Phytonutrients in citrus fruit peel meal and nutritional implication for livestock production. Livestock Research for Rural Development. Volume 19, article \#8 . retrieve November 4, 2017.

Oluremi, B.E. (2008). The role of vitamins and other nutrients in broiler diets. Tropical Animal Health Production,11:199-202.

Oluremi, O. I. A, Igyu, A. D. \& Abu, F. F. (2005). Response of growing rabbits to dietary replacement of maize with sweet orange (Citrus sinensis) Rind. Production Agriculture and Technology 1(1): 130-136.

Oluremi, O.I.A., Ojighen, V.O. \& Ejembi, E.H. (2006). The nutritive potential of sweet orange (Citrus Sinensis) rind in broiler production. International Journal of Poultry Science, 5: 613-617.

Pauzenga, U. (1985). Feeding parent stock. Zootech International. Pp 22-24.

Raza, S., shraf, M.A., Pasha, T.N. \& Latif, F. (2009). Effect of enzyme supplementation of broiler diets containing varying level of sunflower meal and crude fiber. Pakistan Journal of Botany, 41(5): 2543-2550.

SAS, (2008). SAS Users Guide Statistics, SAS inc. Cary, North Califonia, 2008 edition. Seed Storage Compounds: Biosynthesis, Interactions and Manipulation pp. 175-190. Oxford, UK.

TAC (2011). Home page (http://www.nist.gov/tac/2011). 
Tuleun, C.D., Njike, M.C., Ikurior, S.A. and Ehiobu, N.G. (2005). Laying performance and egg quality of hens fed cassava root meal/brewer's yeast slurry based diets. Production Animal Techniques, 1: 148-152. 